\title{
Implementation of Bureaucratic Reform in Government of South Tangerang City
}

\author{
Evi Satispi ${ }^{1}$, Ibnusina Chandra ${ }^{2}$ \\ \{evi.satispi@umj.ac.id ${ }^{1}$, ibnusinach@gmail.com ${ }^{2}$ \} \\ Universitas Muhammadiyah Jakarta, Indonesia ${ }^{1,2}$
}

\begin{abstract}
This research focuses on evaluating the implementation of bureaucratic reform policies implemented by the Government of South Tangerang City, with a focus on institutional bureaucratic reform of the Government Regulation No. 8 of 2016 concerning Formation and Structure of Regional Apparatus. The indicators used in this study are communication, resources, disposition, and bureaucratic structure. This research uses descriptive qualitative method by collecting data based on interviews, observations, and documentation. The results of the research on communication indicators, the purpose of institutional structuring has not fully answered what is the national agenda of building the right institutional functions and the right size, but the institutional structuring policy has been implemented in South Tangerang City. Indicator of Resources, Conditions in the City of South Tangerang, not all Regional Apparatuses are supported by definitive employees (Civil Servants), Dispositions, there is a Disposition regulation policy from the Mandate giver namely the Mayor to the Implementer, but the implementers of the policies do not all guide the disposition. The bureaucratic structure is very clear by paying attention to the task of formulating policies and implementing policies, but some regional apparatuses have not yet developed SOP.
\end{abstract}

Keywords: Bureaucracy Reform, Public Policy, Government.

\section{Introduction}

Bureaucratic reform is a strategic step to build the state apparatus to be more efficient and effective in carrying out the general tasks of government and national development as well as being a driver in realizing good governance. Government bureaucratic reform is very urgent to be implemented when bureaucracy has been considered as a system that causes the running of government and public services to be faltered/slow, long-winded, in-efficient, organizations that are too large and rigid, rampant practices of Corruption, Collusion and Nepotism and bureaucratic problems the other. In general, the problems and challenges of bureaucratic reform:

a) The low commitment from the leadership of agencies both at the central government level and at the regional government level in efforts to prevent and eradicate corruption;

b) The administration of government still does not reflect the administration of a government that is clean and free of $\mathrm{KKN}$;

c) Management of government performance has not been carried out to the fullest;

d) Institutional arrangement that is still ineffective;

e) The application of governance that has not been fully implemented;

f) HR management that has not gone well; 
g) Budget inefficiency or low work culture in making budget efficiency;

h) Management of Public Services is less than the maximum and there are still many illegal levies.

Whereas the Purpose of Bureaucratic Reform is:

a) General

In general, the aim of the bureaucratic reform program is a strategic step to develop the state apparatus to be more efficient and effective in carrying out the general tasks of government and national development towards the Golden Indonesia of 2025. In order to realize the 3 (targets) bureaucratic reform that is set nationally namely

- Regional government that is clean and free of KKN (Corruption, Collusion and Nepotism);

- Quality service;

- Increase the capacity and accountability of performance; and

b) Special

- $\quad$ As well as being a driver for realizing good governance.

As a first step to determine the starting point for implementing a more systematic and synergistic bureaucratic reform, the Government of the City of South Tangerang made efforts for specific objectives including identifying stakeholder/community expectations. The purpose of identifying stakeholder expectations is that the implementation of bureaucratic reform focuses on the needs of stakeholders so that the targets of the bureaucratic reform mentioned above can be achieved according to community expectations.

The Targets of the bureaucracy reform program are to find out the targets of the reform program set by the Central Government to Local Governments, the targets set include in the area of change:

a) Apparatus Resources, Mental Change/mindset \& work culture, implemented at the Personnel Agency, Education and Training

b) Strengthening Supervision by the Inspectorate

c) Strengthening Accountability, Institutional Organization of the Regional Apparatus and Procedures by the Regional Secretariat facilitated by the Organizational Section \& Improving the Performance of the Regional Secretariat Apparatus

d) Improving Public Services, implemented Regional Devices that are in direct contact with Public Services

The indirect target of the bureaucracy reform program is the service user community in South Tangerang City.

\subsection{Research Focus}

This research focuses on evaluating the implementation of bureaucratic reform policies implemented by the Government of South Tangerang City, with a focus on bureaucratic reform of institutional areas Government Regulation No. 8 of 2016 concerning Formation and Composition of Regional Apparatus [1]. 


\subsection{Formulation of The Problem}

The formulation of the problem in this research is how is the implementation of the bureaucratic reform program in South Tangerang City Government?

\subsection{Research Purposes}

Based on the above problem formulation, the purpose of this study is to find out, research and analyze the implementation of the bureaucratic reform program in the Government of South Tangerang City.

\subsection{Benefits of Research}

This research is expected to be useful both for researchers and can improve their qualifications and competencies as teaching staff or lecturers and to improve the qualifications of institutions or institutions of the Muhammadiyah University of Jakarta.

\section{Literature Review}

\subsection{Definition of Implementation}

According to Winarno [2], the notion of implementation is actions that must be carried out by a group of individuals who have been appointed to accomplish a predetermined goal. Usman [3] argues that implementation leads to activities, actions, actions, or the existence of a system mechanism. Implementation is not just an activity, but a planned activity and to achieve the objectives of the activity.

According to Mazmanian and Sabatier [4], understanding implementation is the implementation of basic legal policies also in the form of orders or decisions, or court decisions. The implementation process takes place after a number of stages such as the stage of passing a law, and then the output in the form of implementing a policy decision, and so on until the corrective policy is concerned. Mazmanian and Sabatier [5], the notion of implementation is the understanding that will occur after establishing a program that is the focus of government attention that designs policy implementation. It also said that Implementation was an event that occurred after it was made and ratified by state policy guidelines. Harsono [6], implementation is a process for implementing policies into policy actions from politics into administration. Development of policies in the context of perfecting a program. Wahab [7] argues that implementation is actions carried out both by individuals, officials, or government or private groups aimed at achieving the objectives outlined in the policy decision. Tachjan [8] defines Implementation as public policy is the process of administrative activities carried out after the policy is established/approved. This activity lies between the formulation of policy and policy implementation. Policy evaluation contains top-down logic, which means lower/alternative interpreting.

Meter and Horn [9] provide an explanation of the intended implementation is the implementation of actions by individuals, officials, government agencies or private groups that aim to achieve the objectives outlined in certain decisions. These bodies carry out governmental tasks that have an impact on citizens. 
According to Friedrich [10], implementation is a policy is an action that leads to the goals proposed by a person, group or government in a particular environment in connection with certain obstacles while looking for opportunities to achieve goals or achieve desired goals

\subsection{Definition of Reform}

Sedarmayanti [11], said that reform is a process of systematic, integrated, comprehensive efforts aimed at realizing good governance. Widjaja [12], said that reform is an effort that is intended so that political, government, economic and socio-cultural practices that are considered by the community to be incompatible and not in harmony with the interests of the community and the people's aspirations are changed or reorganized to make it more appropriate and more harmonious (socio-reform).

Prasojo [13], said that reform refers to the intended effort (intended change), in a clear and directed framework, therefore the requirements for successful reform are the existence of a road map, towards a condition, status and objectives set from the beginning along with indicators of their success.

From the explanation above it can be concluded that reform is a change in which there is an effort to make government better according to the wishes of the people. In this case it can be said that to create good governance, it means that the focus of the reform itself is the bureaucracy, because the bureaucracy is the organizing body state affairs. So as to realize good governance, reform must be carried out on bureaucratic bodies.

\subsection{Policy Implementation}

Patton and Sawicki [14] that the implementation is related to various activities that are aimed at realizing the program, which in this position executives arrange ways to organize, interpret and implementing the selected policy. So, by organizing an executive is able to manage effectively and efficiently the resources, units and techniques that can support the implementation of the program, as well as perform interpretations of the plans that have been made, and the instructions can be easily followed for the realization of the program implemented. So, the implementation stage is an event that relates to what happens after a legislation is established by granting authority to a policy by forming a clear and measurable output. Thus the task of implementing the policy as a liaison that allows policy objectives to achieve results through activities or activities and government programs [15].

Nakamura and Smallwood [16] argue that matters relating to policy implementation are success in evaluating problems and then translating into specific decisions. Pressman and Wildavsky [17], implementation is defined as the interaction between the preparation of goals and the means of action in achieving these goals, or the ability to connect in a causal relationship between the desired by the way to achieve it. Jones [18] analyzed the issue of policy implementation by basing on the conception of functional activities. Jones proposed several dimensions and implementation of governance on the programs that have been passed, then determine implementation, also discuss the actors involved, by focusing on the bureaucracy that is an institution executor. So, implementation is a dynamic process that involves continuously efforts to find what will and can be done. Thus the implementation of organizing activities that lead to the placement of a program into the desired policy objectives. 


\section{Thinking Framework}

In this study, researchers wanted to know the implementation of the bureaucratic reform program in the city of South Tangerang, as explained by the Ministry of $P A N$ and $R B$ bureaucratic reform is essentially an effort to carry out fundamental reforms and changes to the system of governance, especially concerning institutional aspects (organization), management (business process) and human resources apparatus.

Various problems/obstacles that cause the system of governance to run or are not expected to work properly must be reorganized or updated. Bureaucratic reform is carried out in the context of realizing good governance. In other words, bureaucratic reform is a strategic step to build the state apparatus to be more efficient and effective in carrying out the general tasks of government and national development.

In addition, with the very rapid advancement of science, information and communication technology as well as changes in the strategic environment requires the government bureaucracy to be reformed and adjusted to the dynamics of community demands. Therefore, steps must be taken that are fundamental, comprehensive, and systematic so that the stated goals and objectives can be achieved effectively and efficiently. Reform here is a renewal process that is carried out gradually and continuously, so it does not include radical and revolutionary efforts and/or actions.

Noting that there are According to Edward III, Grindle, and Mize explained that there are four variables in the implementation of Public Policy or programs including:
a) Communication
b) Resources
c) Disposition
d) Bureaucratic Structure

\section{Research Methods}

This study uses a qualitative research with a descriptive approach, this approach was chosen on the grounds that the qualitative approach can reveal and explain the problem that is the object of the research descriptively. This research was conducted qualitatively because it would observe and trace the policies made by the government of South Tangerang city to be followed up by the regional apparatus. Research location South Tangerang city government is focusing on the bureaucratic reform supporting regional apparatus that directly implements the program. This study seeks to examine how the implementers of the bureaucracy reform in South Tangerang city in 8 areas of change, this program has been running long enough to make governance in public services better. The focus to be studied is the evaluation of program implementation both verbal and non-verbal communication that is seen, generated, formed and constructed by the informant. Data collection techniques from this research are observation, interview, documentation.

The policy analysis of policy implementation uses the theory:

\begin{tabular}{|l|l|}
\hline \multicolumn{1}{|c|}{ Indicator } & \multicolumn{1}{c|}{ Measurement, Nugroho [19] } \\
\hline Communication & $\begin{array}{l}\text { Are the measures and objectives of the policy understood by } \\
\text { the individuals who are responsible for achieving the policy } \\
\text { objectives? }\end{array}$ \\
\hline Resource & Number of staff \\
\hline
\end{tabular}




\begin{tabular}{|l|l|}
\hline \multirow{5}{*}{ Disposition } & Expertise of implementers (professional) \\
\cline { 1 - 1 } & $\begin{array}{l}\text { Relevant and sufficient information to implement the policies } \\
\text { and fulfillment of relevant resources in the implementation of } \\
\text { the program }\end{array}$ \\
\hline & $\begin{array}{l}\text { The existence of authority that ensures that the programcan be } \\
\text { directed to as expected (need leadership support) }\end{array}$ \\
\cline { 2 - 2 } & $\begin{array}{l}\text { There are 2 supporting facilities that are used to carry out } \\
\text { program activities such as funds and infrastructure }\end{array}$ \\
Implementation response to policy (how to behavior attitudes \\
\cline { 2 - 3 } Bureaucratic Structure & $\begin{array}{l}\text { Awareness of the executor, instructions/direction of the } \\
\text { executive to respond the program towards acceptance of } \\
\text { rejection }\end{array}$ \\
\hline Response intensity (number of response) \\
\hline & $\begin{array}{l}\text { The suitability of characteristics in executive bodies that have } \\
\text { both potential and real relationships with what they have in } \\
\text { carrying out policies }\end{array}$ \\
\cline { 2 - 2 } & $\begin{array}{l}\text { Conformity of norms in executive bodies that have both } \\
\text { potential and real relationships with what they have in } \\
\text { carrying out policies }\end{array}$ \\
\hline & $\begin{array}{l}\text { Conformity patterns of relationships that occur repeatedly in } \\
\text { executive bodies that have a relationship both potential and } \\
\text { real with what they have in carrying out policies. }\end{array}$ \\
\hline
\end{tabular}

\subsection{Technical Data Analysis}

Data analysis techniques in this research are; The first stage, data collection and reduction, the second stage, the grouped data is then arranged in the form of narratives, so that it takes the form of a meaningful series of information in accordance with the research problem, the third stage, interpreting the data, the fourth stage, drawing conclusions, and the fifth stage, verify the results of data analysis with the informant

\subsection{Informant Withdrawal Techniques}

Informant withdrawal techniques in this study using purposive and accidental. Purposive addressed to service providers.

\subsection{Data Analysis}

a) Information Gathering

b) Data Reduction

c) Data Presentation

d) Withdrawal of Conclusions/Verification

\subsection{Data Validity}

In this study using triangulation and after researching the collected data will be examined using triangulation techniques to check the validity of the data. 


\section{Results and Discussion}

The discussion in this research is bureaucratic reform focused on institutional strengthening with the analysis of Edward III Theory, namely:

These four factors become important criteria in the implementation of a policy affirmed by Edward III in Juliartha [20] that the main problem of public administration is the lack of attention to implementation that without effective implementation the decision of policymakers will not be carried out successfully. Communication deals with how policies are communicated to organizations and/or the public, the availability of resources to implementation policies, attitudes, and responses from the parties involved and how the organizational structure of policy implementation.

\subsection{Communication}

Success policy requires that the implementor know what to do. What is the purpose and objectives of the policy (target group) so that it will reduce the distortion of implementation. If the objectives and objectives of a policy are unclear or not even known at all by the target group, there may be resistance from the target group.

The objective of the regional device institutional structuring is to develop a governance of governance of the results so that it can be awakened proper institutional function and appropriate size of conditions in South Tangerang the institutional setup is already By establishing a policy in the form of regional Regulation No. 8 of 2016 on regional device formation and structure, the results of institutional observations that have been built have not answered the objective of establishing the right institutional functions and the right size with increasing Regional Apparatus and Structural officials. The target of the regional institutional arrangement is the regional government throughout Indonesia, because it has indeed become the national agenda on the bureaucratic reform program in the organizational area. Noting the above description, the First Indicator of Communication is indicated the occurrence of resistance from the target group with an increased $A P B D$ burden with a poor pattern of rich structure.

\subsection{Resource}

Although the contents of policy has been communicated clearly and consistency, but if the implementation is lacking resources to implement, implementation will not run effectively. These resources can be tangible human resources, namely the implementor competition, and financial resources. Resources are important factors for implementing policies to be effective. Without resources, policies only remain on paper as documents.

Based on observations after the implementation of Regional Regulation No. 8 of 2016 concerning the Formation and Composition of Regional Apparatus of the city of South Tangerang, many HRs who occupy structural positions are held by Non PNS who are Acting Tasks (as in the Head of Section in 54 (fifty-four) Kelurahan in the city of South Tangerang, there are no definitive officials yet, this is an obstacle in providing services to the community because without definitive resources that have full authority in carrying out their duties, they are constrained. 


\subsection{Disposition}

Disposition is the character and characteristics or attitudes possessed by the implementor such as commitment, honesty, nature democratic. If the implementor has a good disposition, then he will be able to run the policy as well as what is desired by policy makers. When the implementor has different characteristics or perspectives from the policy maker, the policy implementation process also becomes ineffective.

Disposing indicators on the implementation of institutional structuring policies are very clear which are regulated in the policy in the form of the South Tangerang Mayor Regulation concerning Position, Organizational Structure, Duties, Functions and Work Procedures of Regional Apparatus, where in the policy it is clear the division of tasks does what to do? in accordance with the authority granted by the Mayor, so that the implementers should be able to guide the condition of the policy of the city of South Tangerang still found several things:

a) Officials do not understand their duties and authority

b) There are duplicated tasks and functions

c) There is no performance contract between the mandate provider and the executor

d) Placement of human resources that implement Disposition is still not fixed yet not in accordance with Job Competency Standards, for example there are officials who have the position of Bachelor of Religion, who are placed as Head of the Land Procurement Division. Based on this it can be concluded that the Disposition is clear but

\subsection{Bureaucratic Structure}

Bureaucratic structure in charge of implementing the policy has a significant influence on the implementation of the policy. One of the important structural aspects of every organization is the existence of standard operating procedures $(S O P)$. SOP is a guideline for every implementor in acting. An organizational structure that is too long will tend to weaken supervision and lead to red tape, which is a complex and complex bureaucratic procedure. This in turn results in inflexible organizational activities.

Portrait in South Tangerang city bureaucratic structure illustrating the policy on Regional Institutional Arrangement very clearly implemented by the Regional Secretariat through the Organization and Performance Division of the Apparatus as the Regional Apparatus which has the task of formulating policies and coordinating the Regional apparatus, maximally and timely implementing what is the mandate of the Central Government, other conditions are still not found compiling SOP that serve as guidelines in carrying out the tasks the new policy implementer will look for and draft $S O P$.

\section{Conclusion}

Based on Edward III's theory related to the implementation of the policy on the structuring of regional apparatuses using PP No. 8 of 2016 in South Tangerang city. In short, inaccurate, clear or consistent guidelines will give Implementors the opportunity to make discretions.

a) Communication indicator, the purpose of institutional arrangement has not yet fully answered what is the national agenda to develop the right institutional function and right size, but the institutional structuring policy has been implemented in South Tangerang city. 
b) Resource indicators, conditions in the city of South Tangerang still not all Regional Apparatuses are supported by definitive employees (Civil Servants).

c) Disposition, there is a Disposition regulation policy from the Mandate giver namely the Mayor to the Implementer, but the policy implementers do not all guide the disposition.

The bureaucratic structure is very clear by paying attention to the task of formulating policies and implementing policies, but some regional apparatuses have not yet developed SOP.

\section{References}

[1] Kota Tangerang Selatan Provinsi Banten, Peraturan Daerah No. 8 Tahun 2016 tentang Pembentukan dan Susunan Perangkat Daerah. Lembaran Daerah Kota Tangerang Selatan, 2016.

[2] W. Budi, "Kebijakan Publik: Teori, Proses dan Studi Kasus," CAPS. Yogyakarta, 2012.

[3] N. Usman, "Konteks implementasi berbasis kurikulum," Jakarta PT. Raja Graf. Persada, 2002.

[4] D. A. Mazmanian and P. A. Sabatier, Implementation and public policy. Scott Foresman, 1983.

[5] P. Sabatier and D. Mazmanian, "The conditions of effective implementation: A guide to accomplishing policy objectives," Policy Anal., pp. 481-504, 1979.

[6] H. Harsono, "Implementasi Kebijakan dan Politik," Bandung PT. Mutiara Sumber Widya, 2002.

[7] S. A. Wahab, "Evaluasi Kebijakan Publik," Malang Penerbit FIA Unibraw dan IKIP, 1997.

[8] D. H. Tachjan, "Implementasi Kebijakan Publik Cetakan 1.” Bandung, 2006.

[9] D. S. Van Meter and C. E. Van Horn, "The policy implementation process: A conceptual framework," Adm. Soc., vol. 6, no. 4, pp. 445-488, 1975.

[10] C. J. Friedrich, "Public policy and the nature of administrative responsibility," Public, pp. 3-24, 1940.

[11] M. S. D. M. R. Sedarmayanti, "Birokrasi dan Manajemen Pegawai Negeri Sipil," Rafika ADITAMA, Bandung, 2009.

[12] H. A. W. Widjaja, Otonomi Daerah dan Daerah Otonom - Haw Widjaya. Jakarta: PT. Raja Grafindo Persada, 2011.

[13] E. Prasojo, Reformasi kedua: melanjutkan estafet reformasi. Penerbit Salemba, 2009.

[14] C. V Patton and D. S. Sawicki, "Basic methods of policy analysis and planning," 1993.

[15] H. N. Tangkilisan, "Implementasi Kebijakan Publik," Yogyakarta: Lukman Offset YPAPI, 2003.

[16] R. Nakamura and F. Smallwood, “The Policy Implementation," New York St. Martin's, pp. 12 $18,1980$.

[17] J. L. Pressman and A. Wildavsky, Implementation: How great expectations in Washington are dashed in Oakland; Or, why it's amazing that federal programs work at all, this being a saga of the Economic Development Administration as told by two sympathetic observers who seek to build morals on a foundation, vol. 708. Univ of California Press, 1984.

[18] G. G. Jones, "The British government and the oil companies 1912-1924: the search for an oil policy," Hist. J., vol. 20, no. 3, pp. 647-672, 1977.

[19] R. Nugroho, "Kebijakan Publik Di Indonesia," Yogyakarta: Pustaka Pelajar, 2016.

[20] E. Juliartha, "Model implementasi kebijakan publik," Jakarta Trio Rimba Persada, 2009. 